\title{
Neck circumference and cardiometabolic risk in children and adolescents: the moderator role of cardiorespiratory fitness
}

\author{
Ana Paula Sehn ${ }^{1 *}$, Caroline Brand ${ }^{1}$, Letícia Welser ${ }^{1}$, Anelise Reis Gaya ${ }^{2}$, Cesar Agostinis-Sobrinho ${ }^{3}$,
} Carlos Cristi-Montero ${ }^{4}$, Elza Daniel de Mello ${ }^{5}$ and Cézane Priscila Reuter ${ }^{1}$

\begin{abstract}
Background: The increased incidence of cardiometabolic risk factors has become a public health issue, especially in childhood and adolescence. Thus, early identification is essential to avoid or reduce future complications in adulthood. In this sense, the present study aimed to verify the influence of cardiorespiratory fitness (CRF) as a moderator in the association between neck circumference (NC) and cardiometabolic risk in children and adolescents.
\end{abstract}

Methods: Cross-sectional study that included 2418 randomly selected children and adolescents (52.5\% girls), aged 6 to 17 years old. Anthropometric measurements, such as NC and body mass index (BMI), and CRF was measured by the six-minute running/walking test, as well as cardiometabolic risk (systolic blood pressure, glucose, HDL-C, and triglycerides), were assessed.

Results: For all age groups, NC showed a negative relationship with CRF. A significant interaction term was found for CRF $\times$ NC with cardiometabolic risk for children (6 to 9 years old), early adolescents (10 to 12 years old), and middle adolescents (13 to 17 years old). It was found that children who accomplished more than $1092.49 \mathrm{~m}$ in CRF test were protected against cardiometabolic risk when considering NC. In adolescents, protection against cardiometabolic risk was found when the CRF test was completed above $1424.14 \mathrm{~m}$ and $1471.87 \mathrm{~m}$ (early and middle stage, respectively).

Conclusions: CRF is inversely associated with NC and acts as a moderator in the relationship between NC and cardiometabolic risk in children and adolescents. Therefore, this detrimental health impact linked to fatness might be attenuated by improving CRF levels.

Keywords: Anthropometry, Pediatrics, Physical fitness, Obesity, Metabolic syndrome

\footnotetext{
* Correspondence: ana_psehn@hotmail.com

${ }^{1}$ Graduate Program in Health Promotion, University of Santa Cruz do Sul

(UNISC), Independência Av, 2293 - Universitário, Santa Cruz do Sul, RS

96815-900, Brazil

Full list of author information is available at the end of the article
}

(c) The Author(s). 2021 Open Access This article is licensed under a Creative Commons Attribution 4.0 International License, which permits use, sharing, adaptation, distribution and reproduction in any medium or format, as long as you give appropriate credit to the original author(s) and the source, provide a link to the Creative Commons licence, and indicate if changes were made. The images or other third party material in this article are included in the article's Creative Commons licence, unless indicated otherwise in a credit line to the material. If material is not included in the article's Creative Commons licence and your intended use is not permitted by statutory regulation or exceeds the permitted use, you will need to obtain permission directly from the copyright holder. To view a copy of this licence, visit http://creativecommons.org/licenses/by/4.0/ The Creative Commons Public Domain Dedication waiver (http://creativecommons.org/publicdomain/zero/1.0/) applies to the data made available in this article, unless otherwise stated in a credit line to the data. 


\section{Background}

The increased incidence of cardiometabolic risk factors such as obesity, and physical inactivity, has become a public health issue, especially in childhood and adolescence worldwide [1, 2]. Thus, early identification is essential for generating strategies and monitoring public health progress to avoid or reduce adulthood complications $[3,4]$.

In this sense, overweight and obesity are strongly associated with the development of cardiometabolic diseases [5-7]. Obesity plays an essential role in metabolic disorders, since leads to a low-grade chronic inflammation increasing the concentration of proinflammatory proteins, such as neutrophils, monocytes, and C-reactive protein [8]. In addition, adiposity influence the development of dyslipidemia, increasing liver adipocytes [9], as well as in blood pressure levels [10], due to an increase of inflammatory markers, such as interleukin- 6 that can cause an increase in C-reactive protein. This increase of $\mathrm{C}$ reactive protein is associated with less nitric oxide that causes lower vasodilation dependent on the endothelium, and consequently enhances the risk of developing cardiometabolic diseases [11]. Therefore, adipose tissue is a complex and highly active metabolic endocrine organ [12].

Anthropometric measures, such as body mass index (BMI) and waist circumference, are the most common tools to identify overweight and obesity in children and adolescents [13, 14]. Also, there is evidence indicating that neck circumference (NC) presents a good correlation with adiposity, BMI, and waist circumference [15, 16], demonstrating accuracy of $77.2 \%$ for diagnostic of obesity [17]. Thus, it is considered an accurate tool for screening and assessing overweight and obesity in different age groups $[15,18-20]$. This measure is simple, practical, and low-cost, as well as it has been suggested as a better alternative than waist circumference [21]. Moreover, NC demonstrates a similar relationship that other adiposity measures with cardiometabolic diseases in childhood [22]. A recent study developed with Brazilian adolescents showed that NC presented good sensitivity and specificity to identify excess weight [23]. Thus, $\mathrm{NC}$ can be used to identify cardiometabolic diseases in the pediatric population [3, 24-26].

In contrast, cardiorespiratory fitness (CRF) has an important role in improving cardiometabolic health, as it is known that when individuals present high CRF levels, lower is their cardiometabolic risk profile $[27,28]$. Evidence indicates that direct measures are more recommended for evaluating CRF related to cardiovascular disease [29], however, indirect measures, such as field tests are also considered as a useful alternative [30-32]. The six-minute running/walking test is commonly used for the evaluation of Brazilian schoolchildren, due to low operating costs, ease of application and the opportunity to evaluate a large number of individuals simultaneously [33, 34]. It is also useful for tracking children and adolescents at risk of developing negative health outcomes [35, 36]. The possible mechanisms by which CRF exerts these benefits are associated to a reduction of low-grade inflammation due to the high utilization of nutrients as a source of energy, mitochondrial biogenesis, reduction of visceral fat and blood lipid profile [37].

CRF seems to be inversely related to NC [24], although this relationship is under-explored in the literature, the association between $\mathrm{NC}$ and cardiometabolic risk is already established. However, there is no evidence indicating the moderator role of CRF in the relationship between these variables, as well as the point at which the level of CRF begins to protect against the development of cardiometabolic diseases. Due to the high prevalence of fatness at the global level and their close relationship with cardiometabolic diseases is relevant to explore factors that could mitigate this unfavorable scenario on the children and adolescent's health status. Taking these aspects into consideration we hypothesized that high CRF levels could counteract the deleterious influence of $\mathrm{NC}$ in cardiometabolic risk. In this sense, the present study aimed to verify the association between CRF and NC and the moderator role of CRF in the relationship between NC and cardiometabolic risk in children and adolescents.

\section{Methods}

This is a cross-sectional study developed with 2418 children and adolescents aged 6 to 17 years old, from private and public schools from the city of Santa Cruz do Sul-RS, Brazil. The sample was randomly selected. Since 2004, the same schools have participated in this research called "Schoolchildren's Health" to form a cohort. For this, a survey was carried out in the city to obtain the number of schools $(n=50)$ and enrolled students $(n=17,688)$. The population density of schoolchildren in all regions of the city, including public (municipal and state) and private schools, was considered to perform the sample size calculation. This study was approved by the Human Research Ethics Committee of the University of Santa Cruz do Sul (UNISC) (number 1.498.305) and followed the resolution $466 / 2012$ of the National Council of Health in Brazil.

The sample size calculation for the present study was performed using the $G$ *Power 3.1 program (HeinrichHeine-Universität - Düsseldorf, Germany). According to Faul, Erdfelder, Buchner, \& Lang [38], the most appropriate statistical test to use is multiple linear regression. As reference parameters it was used: test power (1 $\beta)=0.95$, effect size $\left(f^{2}\right)=0.02$ and significance level $\alpha=$ 0.05 , estimating a minimum sample of 995 individuals. 


\section{Measures}

$\mathrm{NC}$ was measured with the most prominent portion of the thyroid cartilage taken as a reference, with plastic tape, and accuracy of $0.1 \mathrm{~cm}$. Weight and height were assessed through an anthropometric scale with a coupled stadiometer (Filizola ${ }^{\circledR}$ ), while the BMI was calculated through the formula: weight/height ${ }^{2}$. CRF was assessed by the six-minute running/walking test performed on an athletics track, in which the individual should run or walk performing the greatest number of laps. The evaluator noted, and later, added the distance covered by the individuals. The result was obtained in meters. This test followed the protocols by Projeto Esporte Brasil [39].

Sex and ethnicity were obtained through a self-reported questionnaire, in which they should tick one of the following options: sex (female and male) and ethnicity (white, black, brown/mulatto, indigenous and yellow). The criteria proposed by Tanner, established maturation stages, considering figures of breast development in girls and testicular development in boys. For this, the evaluator showed the figures with the different stages, and the individual should indicate which stage he/she was in at the current moment. Five stages were considered, which were subsequently categorized into four categories: prepubertal (stage I), initial development (stage II), continuous maturation (stages III and IV), and matured (stage V) [40]. Blood pressure was measured using the auscultatory method with a sphygmomanometer, a stethoscope on the left arm and, a cuff appropriate to the individual's brachial circumference. It was recommended that the individual remains at rest for $5 \mathrm{~min}$. Two measurements were made, considering the lowest systolic blood pressure. Biochemical parameters (glucose, high-density lipoprotein cholesterol (HDL-C) and triglycerides) were assessed by collecting blood samples after $12 \mathrm{~h}$ of fasting. Analyzes were performed on the Miura 200 automated equipment (ISE, Rome, Italy) using serum samples and commercial Kovalent / DiaSys kits (DiaSys Diagnostic Systems, Germany).

A z-score was used to establish cardiometabolic risk, in which the individual $\mathrm{z}$-score of the following variables is added: systolic blood pressure, glucose, HDL-C, and triglycerides. The $\mathrm{z}$-score was calculated using the following formula: $\mathrm{z}$-score ([value of a continuous variable - cutoff points] / standard deviation). The cutoff points and standard deviation were used as proposed by Stavnsbo et al. [41]. HDL-C has an inverse relationship with cardiometabolic risk, so it was multiplied by -1 . Age and sex were also considered for the calculation of the individual $\mathrm{z}$-score of the variables.

\section{Statistical analysis}

Descriptive statistics were used to characterize the sample. The mean and standard deviation were used for continuous variables and relative and absolute frequency for categorical variables. ANOVA and chi-square were applied to compare groups according to age classification. Generalized linear models were used to verify the direct relationship among CRF, NC and cardiometabolic risk.

Linear regression models were used to test moderation analyzes through the PROCESS macro for the Statistical Package for Social Sciences version 23.0 (SPSS; IBM Corp, Armonk, NY, USA). Children and adolescents present different characteristics of development, thus for a better explanation of the the results within the age groups, the analyzes were divided in children (6 to 9 years), early adolescents (10 to 12 years old), and middle adolescents (13 to 17 years old). The following models have been tested: interaction CRF x NC and cardiometabolic risk in children (6 to 9 years old (Model 1); in early adolescents (10 to 12 years old (Model 2); and in middle adolescents (13 to 17 years old (Model 3). Variables that presented interaction were tested according to the Johnson-Newman technique to establish the moderation point, in which CRF was classified according to tertiles. All analyses were adjusted for sex, ethnicity, and maturational stage. The level of statistical significance was established as $p<0.05$.

\section{Results}

Participant's characteristics are presented in Table 1 according to age classification. Adolescents from 13 to 17 years old showed higher mean values of NC, CRF, systolic blood pressure, glucose, triglycerides, and cardiometabolic risk in comparison with other age groups. In addition, children from 6 to 9 years old, showed higher mean values of HDL-C were observed compared early and middle adolescence group.

For all age groups, NC showed a negative association with $\mathrm{CRF}$, indicating that higher CRF is associated with lower NC (Table 2).

In Table 3 is presented the moderator role of CRF in the relationship between $\mathrm{NC}$ and cardiometabolic risk. A significant interaction term was found for CRF $\mathrm{x}$ NC with cardiometabolic risk in children and adolescents.

Considering the observed interactions, we intend to establish from which point of CRF there was a protection against cardiometabolic risk. Significant association between $\mathrm{NC}$ and cardiometabolic risk were observed in all levels of CRF in children (Fig. 1a), early adolescence (Fig. 1b), and middle adolescence groups (Fig. 1c). Besides, it was found that children who reach more than $1092.5 \mathrm{~m}$ in CRF test were protected against cardiometabolic risk when considering NC. In both adolescent groups, protection against cardiometabolic risk was 
Table 1 Participant's characteristics

\begin{tabular}{|c|c|c|c|}
\hline \multirow[t]{2}{*}{ Characteristics } & \multicolumn{3}{|l|}{ Mean (SD) } \\
\hline & $\begin{array}{l}\text { Children } \\
(n=613)\end{array}$ & $\begin{array}{l}\text { Early Adolescence group } \\
(n=876)\end{array}$ & $\begin{array}{l}\text { Middle Adolescence group } \\
(n=929)\end{array}$ \\
\hline Age (years) & $8.04(0.93)$ & $11.03(0.84)$ & $14.40(1.26)^{a}$ \\
\hline Weight (kg) & $32.79(8.65)$ & $45.27(12.14)$ & $58.24(12.76)^{\mathrm{a}}$ \\
\hline Height (m) & $1.33(0.08)$ & $1.50(0.08)$ & $1.63(0.09)^{\mathrm{a}}$ \\
\hline Body mass index $\left(\mathrm{kg} / \mathrm{m}^{2}\right)$ & $18.35(3.57)$ & $20.08(4.42)$ & $21.82(3.79)^{\mathrm{a}}$ \\
\hline Neck circumference (cm) & $28.13(2.39)$ & $30.19(2.84)$ & $32.58(2.81)^{\mathrm{a}}$ \\
\hline Cardiorespiratory fitness (m) & $832.17(141.92)$ & $860.64(171.42)$ & $950.34(223.95)^{\mathrm{a}}$ \\
\hline Systolic blood pressure $(\mathrm{mmHg})$ & $97.01(11.46)$ & $103.62(11.86)$ & $111.55(11.88)^{\mathrm{a}}$ \\
\hline Glucose $(\mathrm{mmol} / \mathrm{L})$ & $4.75(0.36)$ & $4.92(0.37)$ & $4.92(0.39)^{\mathrm{a}}$ \\
\hline High-density lipoprotein cholesterol (mmol/L) & $1.75(0.28)$ & $1.52(0.27)$ & $1.43(0.26)^{\mathrm{a}}$ \\
\hline Triglycerides (mmol/L) & $0.74(0.33)$ & $0.80(0.35)$ & $0.81(0.37)^{\mathrm{a}}$ \\
\hline Cardiometabolic risk (z-score) & $-0.38(2.34)$ & $-0.32(2.40)$ & $-0.09(2.24)^{a}$ \\
\hline \multicolumn{4}{|l|}{ n (\%) } \\
\hline \multicolumn{4}{|l|}{ Sex } \\
\hline Male & $291(47.5)$ & $367(41.9)$ & $413(44.5)$ \\
\hline Feminine & $322(52.5)$ & $509(58.1)$ & $516(55.5)$ \\
\hline \multicolumn{4}{|l|}{ Cardiorespiratory fitness } \\
\hline Healthy & $451(73.6)$ & $374(42.7)$ & $274(29.5)^{a}$ \\
\hline Risk & $162(26.4)$ & $502(57.3)$ & $655(70.5)$ \\
\hline \multicolumn{4}{|l|}{ Maturational stage } \\
\hline Pre-pubertal & $367(61.6)^{*}$ & $116(13.7)$ & $14(1.5)$ \\
\hline Initial development & $151(25.3)$ & $301(35.6)^{*}$ & $80(8.7)$ \\
\hline Continuous maturation (stage III and IV) & $63(10.6)$ & $399(47.2)$ & $652(71.1)^{\mathrm{a}}$ \\
\hline Maturated & $15(2.5)$ & $29(3.4)$ & $171(18.6)^{a}$ \\
\hline \multicolumn{4}{|l|}{ Ethnicity } \\
\hline White & $510(83.7)$ & $677(77.8)$ & $705(76.5)^{\mathrm{a}}$ \\
\hline Black & $40(6.6)$ & $68(7.8)$ & $64(6.9)$ \\
\hline Brown/mulatto & $59(9.7)$ & $116(13.3)$ & $138(15.0)^{a}$ \\
\hline Indigenous & $0(0.0)$ & $4(0.5)$ & $8(0.9)$ \\
\hline Yellow & $0(0.0)$ & $5(0.6)$ & $7(0.8)$ \\
\hline
\end{tabular}

SD Standard deviation, $n$ number of participants, $\%$ percentage. ${ }^{a}$ ANOVA or chi-square for differences between children, early or middle adolescence groups $(p<0.05)$

Table 2 Association between neck circumference and cardiorespiratory fitness

\begin{tabular}{|c|c|c|c|}
\hline & \multicolumn{3}{|l|}{ CRF } \\
\hline & $\bar{\beta}$ & (95\%) Cl & $p$ \\
\hline \multicolumn{4}{|c|}{ Children } \\
\hline NC & -17.261 & $-21.730 ;-12.791$ & $<0.001$ \\
\hline \multicolumn{4}{|c|}{ Early adolescent group } \\
\hline NC & -12.683 & $-16.517 ;-8849$ & $<0.001$ \\
\hline \multicolumn{4}{|c|}{ Middle adolescent group } \\
\hline NC & -8.200 & $-12.970 ;-3.430$ & 0.001 \\
\hline
\end{tabular}

found when the CRF test distance was above $1424.1 \mathrm{~m}$ and $1471.9 \mathrm{~m}$, respectively.

\section{Discussion}

Findings of the present study indicate that CRF is inversely associated with $\mathrm{NC}$ in children and adolescents of different age groups. Besides, to the best of our knowledge, this is the first study to show that CRF is a moderator in the relationship between $\mathrm{NC}$ and cardiometabolic risk factors. Also, the applied analyzes made it possible to establish the level of CRF that children and adolescents must achieve to protect against cardiometabolic risk when NC is considered. 
Table 3 Moderation of cardiorespiratory fitness in the relationship between neck circumference and cardiometabolic risk

\begin{tabular}{|c|c|c|c|}
\hline & \multicolumn{3}{|c|}{ Cardiometabolic risk } \\
\hline & $\beta$ & $\mathrm{Cl}(95 \%)$ & $\mathrm{p}$ \\
\hline \multicolumn{4}{|c|}{ Children 6 to 9 years old } \\
\hline CRF & -0.004 & $-0.006 ;-0.003$ & $<0.001$ \\
\hline NC & 0.464 & $0.392 ; 0.535$ & $<0.001$ \\
\hline CRF $\times N C$ & -0.001 & $-0.001 ; 0.000$ & 0.001 \\
\hline \multicolumn{4}{|c|}{ Early adolescent group } \\
\hline CRF & -0.003 & $-0.004 ;-0.002$ & $<0.001$ \\
\hline NC & 0.411 & $0.359 ; 0.462$ & $<0.001$ \\
\hline CRF $\times N C$ & 0.001 & $-0.001 ; 0.000$ & 0.019 \\
\hline \multicolumn{4}{|c|}{ Middle adolescent group } \\
\hline CRF & -0.002 & $-0.003 ;-0.002$ & $<0.001$ \\
\hline NC & 0.330 & $0.276 ; 0.383$ & $<0.001$ \\
\hline $\mathrm{CRF} \times \mathrm{NC}$ & 0.000 & $-0.001 ; 0.000$ & 0.003 \\
\hline
\end{tabular}

CRF cardiorespiratory fitness, $\mathrm{NC}$ neck circumference, $\mathrm{Cl}$ confidence interval. All analyses were adjusted for sex, ethnicity, and sexual maturation

The relationship between CRF and different anthropometric indicators has been widely shown in the literature, which includes an inverse association with BMI, waist circumference, and waist to height ratio [42-46]. However, much less is known about the relation between CRF and NC. Our results indicated that CRF is inversely associated with $\mathrm{NC}$, which is in accordance with a study developed with Spanish children and adolescents [24]. As far as we know, the present study is the only evidence in the literature exploring the link between those variables; nevertheless, CRF was not investigated as a primary outcome but as a moderator. Indeed, CRF is a significant health indicator related to the function of different body systems and organs involved in human health status, such as cardiorespiratory, endocrine-metabolic, and musculoskeletal [47, 48].

Also, it is widely described that $\mathrm{NC}$ is associated with some cardiometabolic risk factors in children and adolescents, such as systolic blood pressure, total cholesterol, HDL-C, and clustered cardiovascular diseases risk factors [24-26, 49]. Therefore, these findings indicate that $\mathrm{NC}$ is an effective screening measure for identifying metabolic disease risk also at younger ages.

Taking this evidence into consideration, we intend to go further in order to understand the role of CRF in the association between $\mathrm{NC}$ and cardiometabolic risk. Results showed that the strength of the relationship between $\mathrm{NC}$ and cardiometabolic risk vary according to the level of CRF, highlighting its role as a moderator. This means that in children and adolescents with high CRF levels, there was no longer an association between $\mathrm{NC}$ and cardiometabolic risk factors.
In this study, we also indicated the CRF point from which there was no longer an association between $\mathrm{NC}$ and cardiometabolic risk. In children, this point was $1092.5 \mathrm{~m}$, early adolescents must achieve $1424.1 \mathrm{~m}$, and in the age group, middle adolescents should accomplish $1471.9 \mathrm{~m}$. The reference values for the CRF test applied in the present study indicate that achieving this goal, children and adolescents from all the age groups considered would be classified in the healthy zone for physical fitness [39]. Therefore, to present protection against cardiometabolic risk, they should achieve significantly high CRF levels. In this context, the role of adiposity must be taken into consideration, once it is known that increased body fat is likely to lead to a decrease in fitness levels in children [50], mainly where body weight is lifted or carried over distance (i.e. running), which may intervene in the tests results [51].

Our study adds to the evidence that NC may be an appropriate marker for cardiometabolic health and could be considered mainly in epidemiological studies, as is a more straightforward and more practical anthropometric parameter, not impeded by clothing, ethical questions, or last meal [21]. More importantly, our data bring new evidence showing the crucial role of CRF, once it can protect against cardiometabolic risk when considering NC. Confirming the idea that appropriate levels CRF, indeed, can mitigate the consequences of body adiposity on cardiometabolic health, although our data showed that only very high CRF levels exert a protection. Still, it is suggested that regardless of body weight, it is important to achieve appropriate CRF levels [44, 52, 53]. This aspect is of great relevance, mainly when considering that the development of different cardiometabolic risk factors has its origin in childhood and can be taken to adulthood [54]. Also, CRF is a modifiable factor that can be enhanced through regular moderate to vigorous physical activity practice [55], highlighting its relevance in the context investigated in the present study.

The cross-sectional data limits us from evaluating the effect of changes in CRF in the analyzed variables. Also, the test used to assess CRF is not a direct measure of aerobic capacity, although it is validated and applied in many investigations [2, 56, 57]. The cutoff points and standard deviation used as proposed by Stavnsbo et al. 2018 does not includes children from Latin American countries [41]. This study was strengthened by the large sample size, investigating moderations according to different age groups and mainly determining the moderation point, since there is no evidence in the literature regarding this aspect.

\section{Conclusions}

$\mathrm{CRF}$ is inversely associated with $\mathrm{NC}$ and acts as an essential moderator in the relationship between $\mathrm{NC}$ and cardiometabolic risk both in children and 


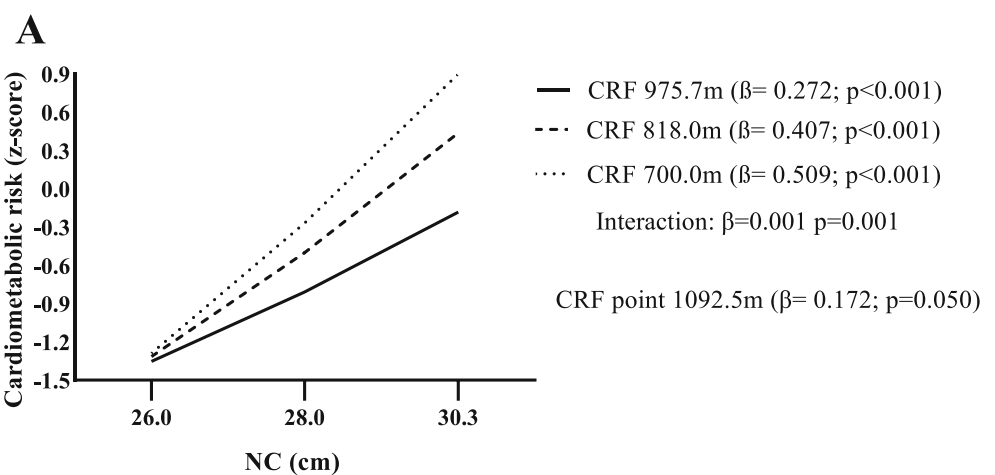

B

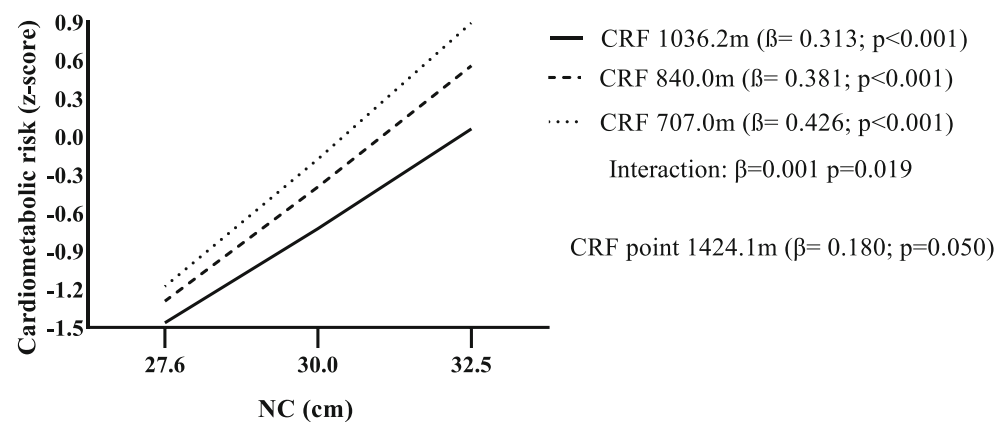

\section{C}

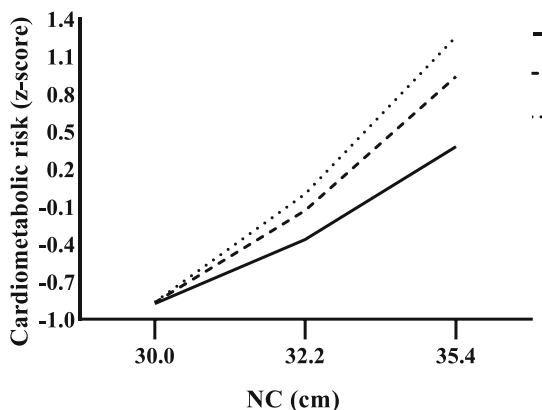

- CRF 1199.0m $(\beta=0.232 ; \mathrm{p}<0.001)$

-.. CRF $913.0 \mathrm{~m}(\beta=0.334 ; \mathrm{p}<0.001)$

… CRF $750.0 \mathrm{~m}(\beta=0.393 ; \mathrm{p}<0.001)$ Interaction: $\beta=0.001 \mathrm{p}=0.003$

CRF point $1471.9 \mathrm{~m}(\beta=0.135 ; \mathrm{p}=0.050)$

Fig. 1 Moderation of cardiorespiratory fitness in the relationship between neck circumference and cardiometabolic risk. a children; $\mathbf{b}$ early adolescents; c middle adolescents; CRF: cardiorespiratory fitness; NC: neck circumference

adolescents. Based on these findings, this detrimental health impact linked to fatness might be attenuated, or even eliminate, by significant improvement in CRF. Thus, this physical fitness marker should be considered in future intervention studies in the pediatric population.

\section{Abbreviations}

BMI: Body mass index; CRF: Cardiorespiratory fitness; HDL-C: High-density lipoprotein cholesterol; NC: Neck circumference; UNISC: University of Santa Cruz do Sul

\section{Acknowledgments}

We thank the collaboration of the schools, our research group from Health Research Laboratory (LAPES), as well as all the support of the University of
Santa Cruz do Sul - UNISC and Higher Education Personnel Improvement Coordination - Brazil (CAPES) - Financing Code 001.

\section{Authors' contributions}

APS, CPR participated in data organization and designed the study. APS, CB and CPR performed the statistical analysis. APS, CB, LW, ARG, CAS, CCM, EDM and CPR contributed to the elaboration of the manuscript with critical comments about it. The authors read and approved the final manuscript.

\section{Funding}

This work was carried out with the support of the Higher Education Personnel Improvement Coordination - Brazil (CAPES) - Financing Code 001.

\section{Availability of data and materials}

The database used and analyzed in the present study is not publicly available as its information may compromise the participants' privacy and consent involved in the research. However, the data are available from the corresponding author (EA), upon request. 


\section{Declarations}

\section{Ethics approval and consent to participate}

This study was approved by the Human Research Ethics Committee of the University of Santa Cruz do Sul (UNISC) (number 1.498.305) and followed the resolution 466/2012 of the National Council of Health in Brazil. The informed consent form for participation in this study was provided by the legal guardian of the participants.

\section{Consent for publication}

Not applicable.

\section{Competing interests}

The authors declare that the research was conducted in the absence of any commercial or financial relationships that could be construed as a potential conflict of interest.

\section{Author details}

${ }^{1}$ Graduate Program in Health Promotion, University of Santa Cruz do Sul (UNISC), Independência Av, 2293 - Universitário, Santa Cruz do Sul, RS 96815-900, Brazil. ${ }^{2}$ Graduate Program in Human Movement Sciences, Federal University of Rio Grande do Sul (UFRGS), Porto Alegre, RS, Brazil. ${ }^{3}$ Faculty of Health Sciences, Klaipeda University, Klaipeda, Lithuania. ${ }^{4}$ RyS Group, Physical Education School, Pontificia Universidad Católica de Valparaíso, Valparaíso, Chile. ${ }^{5}$ Graduate Program in Child \& Adolescent Health, Federal University of Rio Grande do Sul (UFRGS), Porto Alegre, RS, Brazil.

Received: 2 February 2021 Accepted: 30 April 2021

\section{Published online: 17 May 2021}

\section{References}

1. Faienza MF, Chiarito M, Molina-Molina E, Shanmugam H, Lammert F, Krawczyk M, et al. Childhood obesity, cardiovascular and liver health: a growing epidemic with age. World J Pediatr. 2020;16(5):438-5.

2. Gaya AR, Dias AF, Lemes VB, Gonçalves JC, Marques PA, Guedes G, et al. Aggregation of risk indicators to cardiometabolic and musculoskeletal health in Brazilian adolescents in the periods 2008/09 and 2013/14. J Pediatr. 2018;94, 177:-83.

3. González-Cortés CA, Téran-García M, Luevano-Contreras C, Portales-Pérez DP, Vargas-Morales JM, Cubillas-Tejeda AC, et al. Neck circumference and its association with cardiometabolic risk factors in pediatric population. Medicine. 2019;55:1-9.

4. NCD-RisC NRFC (NCD-RWG). Trends in cardiometabolic risk factors in the Americas between 1980 and 2014: a pooled analysis of population-based surveys. Lancet Global Health. 2020;8:e123-33.

5. Chung ST, Onuzuruike AU, Magge SN. Cardiometabolic risk in obese children. Ann N Y Acad Sci. 2018;1411:166-83.

6. Mastroeni SS, Mastroeni MF, Gonçalves MD, Debortoli G, da Silva NN, Bernal RT, et al. Cardiometabolic risk markers of normal weight and excess body weight in Brazilian adolescents. Appl Physiol Nutr Metab. 2016;41:659-65.

7. Pogodina A, Rychkova L, Kravtzova O, Klimkina J, Kosovtzeva A. Cardiometabolic risk factors and health-related quality of life in adolescents with obesity. Child Obes. 2017;13:499-506.

8. Volp AC, Alfenas CG, Costa NM, Minim VP, Stringueta PC, Bressan J. Capacidade dos Biomarcadores Inflamatórios em Predizer a Síndrome Metabólica. Arq Bras Endocrinol Metab. 2008;52:3537-49.

9. Klop B, Willem J, Elte F, Cabezas MC. Dyslipidemia in obesity: mechanisms and potential targets. Nutrients. 2013;5:1218-40.

10. Falkner B. Recent clinical and translational advances in pediatric hypertension. Hypertension. 2015;65:926-31.

11. Teixeira BC, Lopes AL, Macedo RCO, Correa CS, Ramis TR, Ribeiro JL, et al. Marcadores inflamatórios, função endotelial e riscos cardiovasculares. J Vasc Bras. 2014;13:108-15.

12. Romacho T, Elsen M, Rohrborn D, Eckel J. Adipose tissue and its role in organ crosstalk. Acta Physiol. 2014;210:733-53.

13. Alves Junior CA, Mocellin MC, Gonçalves ECA, Silva DA, Trindade EB. Anthropometric indicators as body fat discriminators in children and adolescents: a systematic review and meta-analysis. Adv Nutr An Int Rev J. 2017:8:718-27.

14. Gaya AR, Brand C, Dias AF, Gaya ACA, Lemes VB, Mota J. Obesity anthropometric indicators associated with cardiometabolic risk in
Portuguese children and adolescents. Prev Med Rep. 2017;8:158-62. https:// doi.org/10.1016/j.pmedr.2017.10.002.

15. Asif M, Aslam M, Wyszyńska J, Altaf S, Ahmad S. Diagnostic performance of neck circumference and cut-off values for identifying overweight and obese pakistani children: a receiver operating characteristic analysis. J Clin Res Pediatr Endocrinol. 2020:12:366-76.

16. Taheri M, Kajbaf TZ, Taheri MR, Aminzadeh M. Neck circumference as a useful marker for screening overweight and obesity in children and adolescents. Oman Med J. 2016;31:170-5.

17. Mucelin E, Traebert J, Zaidan MA, Piovezan AP, Nunes RD, Traebert E. Accuracy of neck circumference for diagnosing overweight in six- and seven-year-old children. J Pediatr. 2020;S0021-7557(20):30252-7.

18. Kroll C, Mastroeni SSBS, Czarnobay SA, Ekwaru JP, Veugelers PJ, Mastroeni MF. The accuracy of neck circumference for assessing overweight and obesity: a systematic review and meta-analysis. Ann Hum Biol. 2017;44:66777. https://doi.org/10.1080/03014460.2017.1390153.

19. de Souza MFC, Gurgel RQ, Barreto ÍD de C, Shanmugam S. Neck circumference as screening measure for identifying adolescents with overweight and obesity. J Hum Growth Dev. 2016;26:260-6.

20. Coutinho CA, Longui CA, Monte O, Conde W, Kochi C. Measurement of neck circumference and its correlation with body composition in a sample of students in Saõ Paulo, Brazil. Horm Res Paediatr. 2014;82:179-86.

21. Joshipura K, Muñoz-Torres F, Vergara J, Palacios C, Pérez CM. Neck circumference may be a better alternative to standard anthropometric measures. J Diabetes Res. 2016:6058916.

22. Androutsos O, Grammatikaki E, Moschonis G, Roma-Giannikou E, Chrousos GP, Manios $Y$, et al. Neck circumference: a useful screening tool of cardiovascular risk in children. Pediatr Obes. 2012;7:187-95.

23. Folmann AG, Wolf VLW, Roman EP, Guerra-Júnior G. Neck circumference and excess weight: proposal of cutoff points for Brazilian adolescents. J Pediatr. 2020;97:191-6

24. Castro-Piñero J, Delgado-Alfonso A, Gracia-Marco L, Gómez-Martínez S, Esteban-Cornejo I, Veiga OL, et al. Neck circumference and clustered cardiovascular risk factors in children and adolescents: cross-sectional study. BMJ Open. 2017;7:1-9.

25. Ataie-Jafari A, Namazi N, Djalalinia S, Chaghamirzayi P, Abdar ME, Zadehe SS, et al. Neck circumference and its association with cardiometabolic risk factors: a systematic review and meta-analysis. Diabetol Metab Syndr. 2018; 10:1-34.

26. Kelishadi R, Heidari-Beni M, Qorbani M, Motamed-Gorji N, Motlagh ME, Ziaodini $\mathrm{H}$, et al. Association between neck and wrist circumferences and cardiometabolic risk in children and adolescents: the CASPIAN-V study. Nutrition. 2017:43-44:32-8.

27. García-Hermoso A, Ramírez-Vélez R, García-Alonso Y, Alonso-Martínez AM, Izquierdo M. Association of cardiorespiratory fitness levels during youth with health risk later in life. JAMA. 2020;174:952-60.

28. Mintjens S, Menting MD, Daams JG, van Poppel MNM, Roseboom TJ, Gemke RJBJ. Cardiorespiratory fitness in childhood and adolescence affects future cardiovascular risk factors: a systematic review of longitudinal studies. Sport Med. 2018;48:2577-605. https://doi.org/10.1 007/s40279-018-0974-5

29. Kaminsky LA, Arena R, Ellingsen $\varnothing$, Harber MP, Myers J, Ozemek C, et al. Cardiorespiratory fitness and cardiovascular disease - the past, present, and future. Prog Cardiovasc Dis. 2019;62:86-93.

30. Mayorga-Vega D, Bocanegra-Parrilla R, Ornelas M, Viciana J. Criterion-related validity of the distance- and time-based walk/run field tests for estimating cardiorespiratory fitness: a systematic review and meta-analysis. PLoS One. 2016;11:e0151671.

31. Mayorga-Vega $D$, Aguilar-Soto $P$, Viciana J. Criterion-related validity of the 20-m shuttle run test for estimating cardiorespiratory fitness: a metaanalysis. J Sport Sci Med. 2015;14:536-47.

32. Hamlin MJ, Fraser M, Lizamore CA, Draper N, Shearman JP, Kimber NE. Measurement of cardiorespiratory fitness in children from two commonly used field tests after accounting for body fatness and maturity. J Hum Kinet. 2014;40:83-92.

33. Brand C, Sehn AP, Gaya AA, Mota J, Brazo-Sayavera S, Renner JD, et al. Physical fitness as a moderator in the relationship between adiposity and cardiometabolic risk factors in children and adolescents. J Sport Med Phys fFtness. 2020;60

34. Silveira JF, Barbian CD, Burgos LT, Renner JD, Paiva DN, Reuter CP. Association between the screen time and the cardiorespiratory fitness with 
the presence of metabolic risk in schoolchildren. Rev Paul Pediatr. 2020;38 e2019134.

35. Gaya A, Lemos A, Gaya A, Teixeira D, Pinheiro E, Moreira R. PROESP-Br Projeto Esporte Brasil Manual de testes e avaliação; 2016. p. 1-20.

36. Gonçalves EC, Alves Junior CA, Nunes HE, De Souza MC, Silva DA. Prevalence of Brazilian children and youth who meet health criteria for cardiorespiratory fitness: systematic review. Rev Bras Cineantropometria e Desempenho Hum. 2018;20:446-71.

37. Wedell-Neergaard AS, Eriksen L, Grønbæk M, Pedersen BK, Krogh-Madsen R, Tolstrup J. Low fitness is associated with abdominal adiposity and lowgrade inflammation independent of BMI. PLoS One. 2018;13:1-11.

38. Faul F, Erdfelder E, Buchner A, Lang AG. Statistical power analyses using G*power 3.1: tests for correlation and regression analyses. Behav Res Methods. 2009:41:1149-60.

39. Gaya A, Gaya A. Testing and evaluation manual for the Project Sport Brazil PROESP-BR; 2016. p. 26.Gaya A, Gaya A. Manual de testes e avaliação do Projeto Esporte Brasil - PROESP-BR; 2016, p. 1-26.

40. Tanner JM. Normal growth and techniques of growth assessment. Clin Endocrinol Metab. 1986;15:411-51. https://doi.org/10.1016/S0300595X(86)80005-6.

41. Stavnsbo M, Resaland GK, Anderssen SA, Steene-Johannessen J, Domazet $\mathrm{SL}$, Skrede T, et al. Reference values for cardiometabolic risk scores in children and adolescents: suggesting a common standard. Atherosclerosis. 2018;278:299-306

42. Stoner L, Pontzer H, Barone Gibbs B, Moore JB, Castro N, Skidmore P, et al. Fitness and fatness are both associated with cardiometabolic risk in preadolescents. J Pediatr. 2020;217:39-45.e1. https://doi.org/10.1016/j.jpeds.2 019.09.076.

43. Lee HS, Jeong WW, Choi YJ, Seo YG, Noh HM, Song HJ, et al. Association between physical fitness and cardiometabolic risk of children and adolescents in Korea. Korean J Fam Med. 2019;40:159-64.

44. Cristi-Montero C, Courel-Ibáñez J, Ortega FB, Castro-Piñero J, SantaliestraPasias A, Polito A, et al. Mediation role of cardiorespiratory fitness on the association between fatness and cardiometabolic risk in European adolescents: The HELENA study. J Sport Healh Sci. 2019;8:1.

45. Zaqout M, Michels N, Bammann K, Ahrens W, Sprengeler O, Molnar D, et al. Influence of physical fitness on cardio-metabolic risk factors in European children. The IDEFICS study. Int J Obes. 2016;40:1119-25. https://doi.org/10.1 038/ijo.2016.22.

46. Dyrstad SM, Edvardsen E, Hansen BH, Anderssen SA. Waist circumference thresholds and cardiorespiratory fitness. J Sport Health Sci. 2019;8:17-22.

47. Lang JJ, Tomkinson GR, Janssen I, Ruiz JR, Ortega FB, Léger L, et al. Making a case for cardiorespiratory fitness surveillance among children and youth. Exerc Sport Sci Rev. 2018;46:66-75.

48. Ortega FB, Ruiz JR, Castillo MJ, Sjostrom M. Physical fitness in childhood and adolescence: a powerful marker of health. Int J Obes. 2008;32:1-11.

49. Kuciene R, Dulskiene V, Medzioniene J. Association of neck circumference and high blood pressure in children and adolescents: a case-control study. BMC Pediatr. 2015;15:1-10. https://doi.org/10.1186/ S12887-015-0444-2.

50. Johansson L, Brissman M, Morinder G, Westerståhl M, Marcus C. Reference values and secular trends for cardiorespiratory fitness in children and adolescents with obesity. Acta Paediatr Int J Paediatr. 2020;109:1665-71.

51. Olds TS, Ridley K, Tomkinson GR. Declines in aerobic fitness: are they only due to increasing fatness? Med Sport Sci. 2007:50:226-40.

52. Ortega FB, Ruiz JR, Labayen I, Lavie CJ, Blair SN. The fat but fit paradox: what we know and don't know about it. Br J Sports Med. 2018:52:151-3.

53. Shang X, Li Y, Xu H, Zhang Q, Hu X, Liu A, et al. Independent and interactive associations of fitness and fatness with changes in cardiometabolic risk in children: a longitudinal analysis. Front Endocrinol. 2020;11:342.

54. Bugge A, El-Naaman B, Mcmurray RG, Froberg K, Andersen LB. Tracking of clustered cardiovascular disease risk factors from childhood to adolescence. Pediatr Res. 2013;73:245-9.

55. Braaksma P, Stuive I, Garst R, Wesselink CF, van der Sluis CK, Dekker R, et al. Characteristics of physical activity interventions and effects on cardiorespiratory fitness in children aged 6-12 years-A systematic review. J Sci Med Sport. 2018;21:296-306. https://doi.org/10.1016/j.jsams.2017.07.015.

56. Lorenzi T. Testes de Corrida/Caminhada de 6 e 9 minutos: Validação e Determinantes Metabólicos em Adolescentes. Universidade Federal do Rio Grande do Sul, Porto Alegre, Brasil, 2006.
57. Oliveira L, Braga F, Lemes V, Dias A, Brand C, Mello J, et al. Effect of an intervention in Physical Education classes on health related levels of physical fitness in youth. Rev Bras Atividade Física Saúde. 2017;22:46-53. https://doi.org/10.12820/rbafs.v.22n1 p46-53.

\section{Publisher's Note}

Springer Nature remains neutral with regard to jurisdictional claims in published maps and institutional affiliations.
Ready to submit your research? Choose BMC and benefit from:

- fast, convenient online submission

- thorough peer review by experienced researchers in your field

- rapid publication on acceptance

- support for research data, including large and complex data types

- gold Open Access which fosters wider collaboration and increased citations

- maximum visibility for your research: over $100 \mathrm{M}$ website views per year

At BMC, research is always in progress.

Learn more biomedcentral.com/submissions 